\title{
Transmedia in Brazilian telenovelas: A study of three cases in Rede Globo Television Network
}

Inara Rosas*

DOI: https://doi.org/10.17230/9789587206289ch10

Hanna Nolasco**

\section{Introduction}

Telenovela is, according to Ortiz, Borelli and Ramos (1991, p. 54) "the product par excellence of the Brazilian television system". ${ }^{1}$ Ever since the arrival of television in Brazil by the broadcaster Tupi, in the 1950s, this genre of long serial narratives has established itself as fundamental within the national culture.

As television in Brazil formed as a fusion with other media languages, so did the telenovela when following the structure of long narratives that came before, such as the radionovela. Ever since the radio era, serial narratives have won the national public over, a phenomenon that has only increased with the advent of television. According to Alencar (2004), in the early years of television in Brazil, the networks made versions of telenovelas from Latin-American countries. Only after the success of the genre, did TV. broadcasters begin to invest in completely national products.

Considered a show that represents national identity, the telenovela was consolidated with high ratings as the central television product in Brazil in the 1970's. In that decade, these products began to be exported to many countries, for they gained notoriety through international prizes (Hamburger, 2005). Also, it marked a turning point for the plots, as Brazilian audiences started to claim for stories related to their daily lives (Filho, 2003).

" Bachelor in Social Communication from the Federal University of Paraíba; Master's degree in Communication and Contemporary Culture from the Federal University of Bahia, Brazil. Ph.D. student at Federal University of Bahia. Email: inararosas@gmail.com

"* Bachelor in Social Communication-Journalism from the Federal University of Bahia; Master's degree in Communication and Contemporary Culture from the Federal University of Bahia, Brazil.Email: hannanfl@gmail.com

1 All the quote translations below are ours. 
Telenovela is, to this day, a profitable and popular product. Being one of the most important items in the context of Brazilian television, it "reflects moments in history, launches fashion, interferes with society's behavior, influences other arts, provides social services, anyway, it is connected to the Brazilian citizen's life of all ages and social classes" (Aronchi de Souza, 2004, p. 123).

In this scenario, Rede Globo is the most prominent organization in the telenovelas production and audience engagement from Brazil. It has developed, since the 1960s, a pattern of quality that distinguishes its products from other television networks in the country. Currently, there are other TV. networks such as Record, SBT and Bandeirantes producing teledramaturgy in Brazil, but Globo is still the leader.

The establishment of Globo as a top broadcaster happened for many reasons, amongst which are its technical abilities, which permitted the making of products with high quality standards. Also, Globo offered its audience a consistent programming grid during the week. It had telenovelas and news programs as its main products, each with stable time slots, that helped to increase customers' loyalty (Filho, 2003), allowing this network to stand out by capturing their attention (Ortiz et al., 1991).

Rede Globo's programming grid is already part of the habits of the Brazilian audience, at a point where appointments are made before or after the telenovela (Filho, 2003). That is not the case in the other networks because, even today, they lack specific time slots for airing telenovelas, making it easier for the audience to choose Globo when searching for this specific type of entertainment.

Today, the programming grid of Globo's telenovelas comprises time slots from afternoon to evening. In the early afternoon is shown Vale a Pena Ver de Novo (Worth Seeing Again), a program that reprises past successful telenovelas. Afterwards, Malhação is aired at around 5:00 p.m., Monday through Friday, a show that blends the telenovela and series formats and that has been broadcasted since 1995. The top telenovelas appear on different time slots -at 6:00 p.m., 7:00 p.m. and 9:00 p.m.- from Mondays to Saturdays, eventually having an 11:00 p.m. slot for productions that approach inappropriate themes for younger audiences. With an average of 200 chapters, each with a length of around 50 minutes, telenovelas have different thematic approaches that depend on the time they are on (Campedelli, 1987; Hamburger, 2005). The 6:00 p.m. telenovela is 
generally a historic production; the 7:00 p.m. telenovela is lighter, with comedy and romance; and the 9:00 p.m. telenovela, aired at Globo's prime time, has the biggest financial investment and approaches more "serious" questions within daily life.

\section{The notion of transmedia storytelling and the telenovela product}

Transmedia storytelling is a contemporary way of telling stories; rather than a single cultural product in a single media, the consumer has access to a tangle of pieces in various media platforms (Lessa, 2017). Yvana Fechine et al. (2013) explains the phenomenon:

We understand transmediation as a production model oriented by the distribution of contents in different media and technological platforms associated with each other and whose articulation is anchored in interactional strategies and practices promoted by the participatory culture stimulated by the convergence environment (p. 26).

According to Rodrigo Lessa (2017), transmedia is an adjective, a quality or characteristic to be attributed to products and languages. It is a recent phenomenon: in the late 1990s the first transmedia experiences gained some popularity, but it was only after the turn of the century that cultural critics and academic researchers began to make them their object of research. Transmedia is a work in process: to date, nearly two decades later, entertainment industry producers are still experimenting with new ways and tools to expand narratives toward diverse media platforms.

Transmedia narrative is reconfigured after each new experience, with each re-creation, and it depends on the producing company, the type of product and the consumer public. As it has been already mentioned, Rede Globo is the largest producer of Brazilian telenovelas, which now aims at developing transmedia content for its fictional productions. According to Fechine (2014), since 2010, the broadcaster has systematically and admittedly invested in transmedia actions in telenovelas, and during the last seven years it has been possible to observe the most varied and increasingly complex experiences.

A specificity of telenovelas is that they are long duration serial narratives that are exhibited every day except for Sunday, with a central plot 
intertwined with several secondary ones. In such a complex narrative, it is difficult to find expansion possibilities that favor the creation of other stories. According to Souza, Lessa, \& Araújo (2013), there are two predominant uses of transmedia in Brazilian telenovelas:

the first is the use of a variety of applications and games that promote immersion at the telenovelas fictional universe, allowing the public to explore details of the characters, plots, setting, costumes and fictional cities [...] The second strategy is the use of fictional websites (of institutions that only exist within the telenovelas) and blogs and characters profiles in social media websites (2013, p. 325).

Recently, the broadcaster has made more complex attempts, such as webseries and other modes that not only expand the fictional universe but also configure storytelling, as it occurs in the following case studies.

\section{Results: transmedia experiences within Brazilian telenovelas}

As Lima and Moreira (2012) indicate, networks in Brazil have actively tried to promote a dialogue between the telenovela's narratives and content in other medias, to increase the interaction between the audience and the plot. Thanks to Globo's prominence, this broadcaster was also able to start experiencing with transmedia strategies before other networks in the country. To this day, only two other networks have made transmedia actions within their telenovelas: Record and SBT. As pointed out by Souza et al. (2013), it is also important to highlight that Bandeirantes has experienced with transmedia, but within its series, not its telenovelas.

Balacobaco (2012-2013), the only telenovela from Record that contained transmedia actions, had a fictional radio station in its plot, called Ampola, that was available online, enabling the audience to immerse themselves in the telenovela's fictional universe. In addition, the public could request songs and make playlists (Souza et al., 2013).

SBT has developed several relevant telenovelas and series for younger audiences within their trajectory, where many of them are Mexican or Argentinian productions reprises or versions. It is within this type of products that this network has been including transmedia extensions. Carrossel (2012-2013) was the Brazilian version of a Mexican telenovela that did not include transmedia actions in its first exhibition. However, 
as it ended, SBT developed some enterprises that expanded Carrossel's fictional universe by creating a type of transmedia franchise with diverse autonomous products.

This transmedia universe was composed by: the telenovela, aired between 2012 and 2013; the two movies that premiered in 2015 (Carrossel: the movie) and 2016 (Carrossel 2: the disappearance of Maria Joaquina); the series Patrulha Salvadora, a spin-off aired between 2014 and 2015, that brought some of Carrossel's characters into a different environment; an animated cartoon aired in the time slot previous to the reprise of the telenovela in 2016, which was also available online; and, in 2017, a musical theater production that is currently active. Although this network is not fully experienced with transmedia, the development of a franchise was a relevant initiative.

Globo began its experience with transmedia with small actions, such as characters' blogs and fictional websites. In Viver a Vida (2009-2010), the character Luciana, who became quadriplegic after an accident, had a blog called Sonhos de Luciana (Luciana's Dreams) where she shared stories about her life changes and recovery process. Globo also had a website called Portal da Superação (Overrun Portal) with testimonials of real people who lived with this condition but managed to overcome their limitations.

In 2011, this broadcaster created an Internet team which has participated in almost all telenovelas ever since, and whose field of action does not necessarily rely on the transmedia strategy: depending on the product, this team can manage aspects such as online advertising and the telenovela's website. ${ }^{2}$ Its relevance, though, was due to the expansion of Globo's presence in other media. The beginning of this team's action was with the telenovela Morde e Assopra (2011), aired at 7:00 p.m., that contained the blog Caçadora de Dinossauros (Dinosaur Hunter) and the game $O$ segredo de Naomi (Naomi's secret). The first was Júlia's blog, a paleontologist who shared stories about the process of finding fossils. The latter was a game that brought the audience some facts about Naomi, a character that would be central towards the end of the plot (Lessa, 2017).

2 The information about the Internet team was gathered at Memória Globo (www.memoriaglobo. com.br), a memory website for this broadcaster that brings information about its products. As the network lacks specificities about each team's action within every telenovela, the group's role may vary. 
During the same year, there were also two other telenovelas that explored transmedia strategies: O astro, aired at 11:00 p.m., had a webseries called Sob o signo de Ferragus that told the story of the protagonist's past in seven episodes online, while Cordel Encantado, at 6:00 p.m., made an online fictional documentary directed by a character in the plot.

In 2012, the broadcaster aired Amor Eterno Amor (2012), a 6:00 p.m. telenovela centered on the story of Rodrigo, a main character who had disappeared when he was a child. Globo created, then, the first documentary webseries as a transmedia extension to a telenovela called Repórter Investigativo: caso Rodrigo Barros (Investigative Reporter: The Rodrigo Barros case), which had three episodes and provided evidences to solve the case. This initiative, and also TV Orelha, a transmedia action within Malhação, were nominated for being designed for digital platforms at the 2013 International Digital Emmy Awards. ${ }^{3}$

More recently, Haja Coração (2016), a 7:00 p.m. telenovela, had an animated cartoon of Tito, the dog that was the telenovela's mascot, available on YouTube and Globo Play. ${ }^{4}$ Eta Mundo Bom (2016), a 6:00 p.m. telenovela, was created in parallel with a radionovela and a web documentary that commented the Brazilian cinema from the 1940's as transmedia content, decade in which the telenovela took place.

Although this communication strategy had already been used in Brazilian television shows for more than a decade, it was with Cheias de Charme (Sparkling Girls, 2012) that Rede Globo did a strategic and systematized use of the transmedia phenomenon, by organizing a specialized team to act within many fronts of transmedia actions, such as music videos, websites and book releases. This strategy has become popular in Brazil, since it promotes better reception and quality. Avenida Brasil (2012), besides the official transmedia content, offered a massive production created by fans and the press, due to the immense repercussion of the show (Cerqueira \& Lessa, 2015). Totalmente Demais (Totally Awesome, 2015-2016) had a webseries, the first case of an online spin-off in a Brazilian telenovela.

3 Informations gathered at: https://glo.bo/2LH3F3d (Accessed in September 5th, 2017).

4 Globo Play is Rede Globo's streaming website. 


\section{Avenida Brasil: a transmedia built with social media}

Avenida Brasil was a 9:00 p.m. telenovela, written by João Emanual Carneiro and directed by Amora Mautner and José Luiz Villamarim since 2012, was composed by 179 chapters. Its central plot was the revenge of Nina against her former stepmother Carminha, who had scammed her father in the past, and while in charge of Nina when still a child, had made them live in a dumping ground.

It was a telenovela of multiple successes. It had a massive audience, it was widely commented by the press and it was exported to more than 150 countries abroad, being the highest rate achieved by Rede Globo. It also mobilized academic research that approached the telenovela in many ways, from being a popular product that focused on the rise of the working class, to a phenomenon of the second screen, where Avenida Brasil represented the peak of this type of resonance in Brazilian telenovelas, and also for its stylistic and plot innovations (Cerqueira \& Lessa, 2015; Pucci, 2013; Rosas, 2015).

According to Borelli (2011), the approximation of fiction content to the reality of the spectator seems to be one of the great changes in the traditional way of making telenovelas. In the case of Avenida Brasil, there was a thematic approach (the recent rise of a lower social class) which followed a cultural and economic logic and a media reception approach, considering the new tools of communication and technology -by presenting television fiction using the Internet, and specially the social media as an ally (Lopes \& Mungioli, 2011).

In the plot, Monalisa owns a beauty parlor, which is frequented by some other characters. The more standard transmedia extension used in Avenida Brasil was the blog Dicas da Monalisa (Monalisa's tips), with beauty tips related to the parlor written by the hairdresser Monalisa and her friend Olenka, a manicure/pedicure professional. In a very colloquial language, using slang they both say in the telenovela, the blog posts had tips of the character's visuals and the readers could learn how to make Olenka's decorated nails, for example. It also had content for special dates, such as Olenka's red lipstick for Valentine's Day, and, when Monalisa got married in the plot, there was a post about her wedding along with makeup tips for brides. 
However, most of the transmedia content created for this novela aimed at the public engagement with the product itself and not at expanding its narrative. This research offers two hypotheses about the transmedia phenomenon in Avenida Brasil. The first one is that the time slot of the telenovela, 9:00 p.m., demands more elaborate plots and longer chapters, not having much space for narrative extensions, since the telenovela explores its plots deeply. The second is related to the present moment of media convergence and participative culture, in which the broadcaster intends to conquer its audience by getting it involved with the telenovela through the use of popular language in social media and the Internet, such as gifs and memes.

This content production was almost entirely concentrated on the telenovela's website, but also using the official Rede Globo Fanpage on Facebook to share these extensions. The telenovela inspired a true phenomenon of social network interaction on Facebook and Twitter. Throughout its period on the screen, between March and October 2012, the novela became Internet's favorite subject. On Twitter, the hashtag \#OiOiOi, which refers to the opening song credits, reached the trending topics in almost all chapters of the plot. In its final chapter, seven out of the ten most commented subjects of Brazil on Twitter referred to Avenida Brasil (Ortiz, 2013).

Avenida Brasil transmedia privileged content that could get the fastest repercussion online, including gifs, photomontages with characters' sayings, and everything that could easily become a meme. In the official telenovela's website there was an application that allowed its users to have the effect of "freezing" their personal photos, trademarked at the end of each chapter. The application was launched the same day as chapter 100 , along with the campaign "Who should be 'frozen' at the end of the novela?", where users could vote for some characters. Although the vote took place on the official telenovela's website, much of the publicity of this campaign took place on Facebook.

There was also interactive media, such as games and quizzes. A seven errors game about the setting, and the games Quem manda melhor (Who is the best? ?), where the user watched videos of fights between Carminha and Nina to later vote for the winner, produced a score to share on social media. There was also Maltrate os Vilões (Mistreat the Villains), where the users hit balls on the telenovela villains with a mouse command. This kind of content is more often called transmedia reception (Fechine et al., 2013). 
This transmedia reception engaged the fans to create their own content. Although this practice was not approved by the broadcaster, it impacted as much as the official content. There were many Tumblr's making gifs, photomontages, bringing new situations to the plot; on Facebook, there was the fanpage Conselhos de Carminha (Carminha's advices) with sentences that Carminha could possibly say about different situations; on Twitter, there were also fake profiles of characters.

\section{Cheias de Charme: a distinctive mark within Globo's expe- rience with transmedia}

Also released on 2012, Cheias de Charme (Sparkling Girls) was a telenovela written by Izabel de Oliveira and Filipe Miguez, and directed by Carlos Araújo. This product is a distinctive mark within Globo's trajectory with transmedia narratives. The network had already experienced with transmedia before, but in this telenovela Globo created an enterprise with unprecedented actions, such as the launch of online materials prior than on television, a book release and campaigns on social media.

The "sparkling girls", protagonists of the telenovela, were Maria do Rosário, Maria da Penha and Maria Aparecida. Three housemaids of different ages and trajectories, they met at a police station due to different problems, became good friends, and later formed a musical group called "Empreguetes". 5

The show's main characters were singers -the group Empreguetes, the "prince of housemaids" Fabian and the villain Chayene- and music was an important part of the narrative, which is why the authors chose to elect video clips as key to the transmedia strategy of this telenovela.

Vida de Empreguete (Life as a Housemaid) was a song ${ }^{6}$ composed by Rosário at her job, on a day where her employer Chayene travelled and Penha and Cida came to visit her. The three women enjoyed the moment and explored the singer's house. As Rosário composed the song, she suggested her friends to record it there, since there was a recording studio inside the house. Later on, they decided to also make a video to keep a

5 The name of the group, "Empreguetes", is a play on words with the term housemaid in portuguese, "empregada doméstica".

6 Many songs from this telenovela were originally composed to serve the plot, such as Vida de Empreguete and Nosso Brilho, two of the Empreguetes work songs that were turned into video clips. 
souvenir of the moment, and called their producer friend Kleiton to help with these activities.

This video clip was kept a secret because of the possible legal consequences that could arise with its revelation, mainly since it was filmed without consent, also bringing a parody portrayal of the housemaid's bosses, that exploited them on the job. Unfortunately, for them, a character found this material and took it to Chayene, who was furious and decided to take legal action. In this process, the video was accidentally put online, and it was the cause of the protagonist's transformation from simple housemaids into popstars.

As the video was disclosed within the plot, Globo also "leaked" it to the spectators, through the telenovela's official website. Narratively, at the end of the chapter, there was a take of a few seconds focused on Chayene's computer, that introduced the link www.globo.com/empreguetes. At the chapter's final credits, the information was reinforced, and when the spectators got into this website, they had access to the secret video clip. This material was only exhibited at the telenovela the next Monday, enabling the audience to access it online during the whole weekend before it aired on television. It was a transmedia resource that had not been used in Brazilian telenovelas and that was successful: there were over 12 million accesses to the video on that weekend, according to $\mathrm{Me}$ mória Globo. They repeated this strategy with the other telenovela video clip, Nosso Brilho (Our Sparkle), with the infiltration occurring similarly, revealing suspense and also the strategies to show the link to the website.

Other transmedia actions within this telenovela included character's websites, such as Tom Bastos Estrelas do Tom (Tom's Stars), in which the manager of the main singers shared information about his clients and also promoted contests for public interaction. There were two contests that happened online, with the results being shown to the Empreguetes within the chapter of the telenovela, on television. Globo promoted these actions in order to try to control where the fan made products were distributed, for this broadcaster "acts judicially to restrain at social media the circulation of content arising from its programs, that is protected by copyright and intellectual property laws" (Castro, 2012, p. 7).

Also, there were campaigns that allied the telenovela with the Internet, mainly through social media. At the time of the Empreguetes arrest because of the illegally made video clip, the campaign Empreguetes Livres 
(Free Empreguetes) was launched, and the hashtag \#empregueteslivres became a trending topic on Twitter (Castro, 2012). The other campaign, Empreguetes Para Sempre (Empreguetes Forever) boosted the audience interaction, including that with real Brazilian singers that sent testimonial videos to the website -some also shown at the telenovela-, asking for the return of the group. The treatment of fictional music artists as colleagues by the real singers contributed to the spectator's immersion in the telenovela's fictional universe.

Lastly, there was also a book release, Maria Aparecida's diary, called Gida: a empreguete - um diário intimo (Cida: the Empreguete - an intimate diary). Within the plot, the young character wrote her life experiences in a diary, in a make-believe conversation with her deceased mother. This diary was published within the telenovela, and when the novela ended there was an actual book release, and this product can still be bought at local main bookstores.

These transmedia actions contributed to the success of Sparkling Girls, that was the telenovela with highest ratings when compared to others displayed within the same time slot over the previous four years. ${ }^{7}$ These strategies helped to disguise the borders between fiction and reality (Lima \& Moreira, 2012), enabling the audience to be immersed at the fictional universe, like when they played and made parodies of the character's songs and video clips just as if they were real artists.

\section{Totalmente Demais: Rede Globo engages in a more complex transmedia strategy}

Totalmente Demais (Totally Awesome) was a 7:00 p.m. telenovela aired between November 2015 and May 2016, written by Rosane Svartman and Paulo Halm and directed by Luis Henrique Rios. The plot was inspired by the play Pygmalion by Bernard Shaw and the movie My Fair Lady (1964). In the following paragraphs the novela will be referred as TD.

The plot is centered on Eliza, an impoverished young woman from the countryside who pursues a career in modeling after being discovered by Arthur, owner of the modeling agency Excalibur, and wins the contest Totalmente Demais Girl promoted by a fashion magazine homonym to

7 According to ratings present at UOL website. Available at https://bit.ly/2BLOxwR (Accessed in september 4th, 2017). 
the telenovela's title. It established a love triangle between Eliza, Arthur and Jonatas, a boy who does informal commerce on the streets and the person who helped her when she moved to Rio de Janeiro while escaping from her stepfather, after being harassed by him.

In parallel, there is the fashion ensemble, composed around Totalmente Demais magazine, whose director is Carolina, an ambitious businesswoman. She maintains an unorthodox love relationship with Arthur, changed when Eliza gets in the picture. Carolina and Arthur both head the contest won by the protagonist. There is also the humor ensemble, formed by residents of Fátima, a humble neighborhood where Carolina was raised, where her older sister Dorinha lives with her husband Zé Pedro and their two kids, and where her first boyfriend Hugo also lives, with his two daughters, Cassandra and Débora, and with whom Carolina denies any relationship.

As already mentioned, the 7:00 p.m. telenovelas bring lighter plots, focused on romance and humor. TD captivated the public, with ratings not attained since Cheias de Charme (2012) in that time slot. The expressive audience made the broadcaster extend the telenovela's chapters, and the final chapter was aired on a Monday, which had only happened twice before in Rede Globo. ${ }^{8}$

After a systematized and successful experience from Sparkling Girls, Totalmente Demais defined a new phase of multiplatform content produced by Rede Globo. There were many strategies, concerning crossmedia and transmedia. The production dialogued with other areas from Globo's conglomerate in crossmedia actions, such as when Mônica Salgado, editorial director of Glamour Magazine participated in a telenovela chapter. In the last TD chapter, there was a crossover with its successor Haja Coração (2016), when the character Fedora, a famous fashion blogger, visited the head office of Totalmente Demais magazine.

Among the transmedia content of TD, there was the website of Totalmente Demais magazine, with news and reports from this fictional universe, such as fashion editorials, travel and behavior tips, stories and backstage videos about the Totalmente Demais Girl contest. Between

8 Novelas usually end on Fridays and have their last chapters reprised on Saturdays. Like TD, the telenovela Estúpido Cupido (1977) also ended on a Monday and Anjo Mau (1976) on a Tuesday. Information contained in https://goo.gl/q9r7Ha (Accessed in September 6th, 2017). 
the contest launch and the final result there were two and a half months of telenovela's chapters, with several events reflecting Eliza's coming of age. There was also another website made: the fashion blog Visu da Lu, owned by Carolina's personal assistant.

In TD Globo developed new formats that had never been done before, to expand the narrative of the main product. There was a chapter zero with a 6-minute duration, a prologue where it was possible to know a little about the story and its characters, previously shown on the streaming Globo Play and on Gshow, the broadcaster's website dedicated to paratextual content from Globo's shows.

The most complex transmedia content created by Rede Globo so far is Totalmente Sem Noção Demais, a 10-episode webseries that centered on the neighborhood of Fátima: Carolina's sister's and Hugo's families. The series debut happened in Globo Play and in Gshow the day after the end of TD. During the following month, the series was aired in a shorter version in Video Show, a variety program that approaches Globo's shows backstage. This TV series, besides a transmedia extension, was Globo's first online spin-off.

Another online transmedia storytelling originated from a partnership between Globo's Digital Media Marketing area and the publicity agency Lew'Lara|TBWA, in which a branded content of Risqué, a nail polish brand, was made on the website of Totalmente Sem Noção Demais, and also had activation actions within the spin-off episodes. ${ }^{9}$

With these strategies, Totalmente Demais, as well as the previous case studies, had a strong presence in social media. On Twitter, for example, almost every chapter reached the trending topics, especially because of fans disputing between the couples Eliza and Jonatan (\#Joliza) vs. Eliza and Arthur (\#Arliza).

9 Information obtained from https://goo.gl/MKaZrH (Accessed in September 6th 2017). 


\section{Conclusion}

Within the current context of fiction consumption related to media convergence, transmedia has gained more enthusiasm with time. Therefore, entertainment industries have focused on building more elaborate products that surpass public's expectations.

In telenovelas -with Brazil being a reference in the production of these items-, the broadcasters were also engaged with this type of content production, aimed at enriching their narratives and matching international productions. In less than a decade the transmedia experiences in telenovelas not only increased their quantity, but also became even more elaborate, including the participation of specialized consulting teams.

Through the analysis of this article's corpus, it was observed that each telenovela has particularities that are evoked by format and genre specificities, such as time slot, length, and thematic. Therefore, there are different possibilities of transmedia extensions depending on the type of telenovela. Additionally, most of Globo's transmedia projects, including the more elaborate ones, occurred at 7:00 p.m. telenovelas. This article sustains that this time slot contains narratives with shorter chapters and lighter plots that enable the creation and offer of associated products. An example is the humor ensemble of Totalmente Demais, that turned into a sitcom webseries.

Moreover, it is noted that the 6:00 p.m. productions also include similar projects, although historical narratives limit the extension of transmedia actions. Regarding 9:00 p.m. telenovelas, the transmedia proposals are generally simpler, due to the high complexity of the plots. At the same time, a wide public engagement was observed, by virtue of easily shareable contents, as it happened with Avenida Brasil.

As for Sparkling Girls, its high ratings and active public participation (Bieging, 2013) left a mark within Brazilian telenovelas, also inspiring this network to move forward with its experimentation with transmedia content. That led to the transmedia enterprise of Totalmente Demais, 
with unprecedented actions. Beyond becoming a milestone in elaborate narrative content, its crossmedia actions may possibly inaugurate a new stylistic mark of the 7:00 p.m. telenovelas: the final chapter of TD introduced the plot of Haja Coração, and its successor Rock Story's ending also introduced the plot of Pega-Pega, telenovela aired at the time this article was written. 


\section{References}

Alencar, M. (2004). A Hollywood brasileira: panorama da telenovela no Brasil (2nd ed.). Rio de Janeiro, Brazil: Senac Rio.

Aronchi de Souza, J. C. (2004). Gêneros e formatos na televisão brasileira. São Paulo, Brazil: Summus.

Bieging, Patrícia. (2013). Transmidiação como Ferramenta Estratégica: Cheias de Charme Explora uma Nova Forma de Fazer Telenovela. Revista Novos Olhares, 2(2), 60-71. Available in https://bit.ly/2rZL3T5 Borelli, S. H. S. (2011). Migrações narrativas em multiplataformas: telenovelas Ti-Ti-Ti e Passione. In M. I. V. Lopes (Org.), Ficção televisiva transmidiática no Brasil: plataformas, convergência, comunidades virtuais (pp. 61-120). Porto Alegre, Brazil: Sulina.

Campedelli, S. Y. (1987). A telenovela. São Paulo, Brazil: Ática.

Castro, G. (2012). Cheia de Charme: a classe trabalhadora no paraíso da cibercultura. Paper presented at the anual meeting of Intercom, Fortaleza, Brazil, September 3-7.

Cerqueira, R. C. B., \& Lessa, R. (2015). Avenida Brasil e o Lugar da Recepção: Uma Análise das Percepções Sobre João Emanuel Carneiro no Twitter. Ação Midiática, (9), 1-18. Available in https:// bit.ly/2TjKsay

Fechine, Y. (2014). Transmidiação e cultura participativa: pensando as práticas textuais de agenciamento dos fãs de telenovelas brasileiras. Revista Contracampo, 31, 5-22. doi: 10.5327/Z22382577201400310694 Fechine, Y., Gouveia, D., Almeida, C., Costa, M., \& Estevão, F. (2013). Como pensar os conteúdos transmídias na teledramaturgia brasileira? Uma proposta de abordagem a partir das novelas da Globo. In M. I. V. Lopes (Ed.), Estratégias de Transmidiação na Fiç̧ão Televisiva Brasileira (pp.19-60). Porto Alegre, Brazil: Sulina.

Filho, D. (2003). O circo eletrônico: fazendo TV no Brasil (2nd ed.). Rio de Janeiro, Brazil: Zahar. 
Hamburger, E. (2005). O Brasil Antenado: A Sociedade da Novela. Rio de Janeiro, Brazil: Zahar.

Lessa, R. (2017). Explorações conceituais acerca de narrativa transmídia e ficção seriada televisiva. In I. F. Cunha, F. Castilho, \& A. P. Guedes (Eds.), Ficção televisiva seriada no espaço lusófono (pp. 87-105). Covilhã, Portugal: LabCom.IFP.

Lima, C., \& Moreira, D. (2012). Operações do conceito de hipertelevisão na novela Cheias de Charme: a criação de universos transmídias na TV Globo. Paper presented at the anual meeting of Intercom, Fortaleza, Brazil, 2012 September 3-7.

Lopes, M. I. V., \& Mungioli, M. C. P. (2011). Ficção televisiva transmidiática: temas sociais em redes sociais e comunidades virtuais de fãs. In M. I. V. Lopes (Org.), Ficção televisiva transmidiática no Brasil: plataformas, convergência, comunidades virtuais (pp. 241-296). Porto Alegre, Brazil: Sulina.

Ortiz, J. (2013). Configurações da experiência televisiva: o consumo social na internet (Master's thesis in Media Studies). Universidade Federal da Bahia, Salvador, Brazil. Retrieved from https://repositorio.ufba. br/ri/handle/ri/25188

Ortiz, R., Borelli, S. H. S., \& Ramos, J. M. O. (1991). Telenovela: história e produção (2nd ed.). São Paulo, Brazil: Brasiliense.

Pucci, L. R. (2013). Inovações estilísticas na telenovela: a situação em Avenida Brasil. Anais do XXII Encontro Anual da Associação Nacional dos Programas de Pós-Graduação em Comunicação, Salvador, Brazil, June 4-7. Available in https://bit.ly/2VgePjU

Rosas, I. (2015). Central do Brasil e Avenida Brasil: um olhar nas marcas estilísticas do roteirista João Emanuel Carneiro. In Avanca Cinema Internacional Conference 2015. Avanca, Portugal: Edições CineClube de Avanca.

Souza, M. C. J., Lessa, R., \& Araújo, J. (2013). Empresas produtoras, projetos transmídia e extensões ficcionais: notas para um panorama brasileiro. In M. I. Lopes (Ed.), Estratégias de Transmidiação na Fïção Televisiva Brasileira (pp. 303-344). Porto Alegre, Brazil: Sulina. 